\title{
Analisis Budaya Khitbah Nikah oleh Perempuan Kepada Laki-laki di Desa Jatisari Senori Tuban
}

\author{
Ihda Shofiyatun Nisa', Abdul Mufidi Muzayyin, Ali Muhrizam \\ Institut Agama Islam Nahdlatul Ulama Tuban, UIN Walisongo Semarang, \\ Institut Agama Islam Nahdlatul Ulama Tuban \\ E-mai: ihdashofiya95@gmail.com, abdulmufidimuzayyin@gmail.com, \\ ,Rizam1922@gmail.com
}

\begin{abstract}
Abstrak: Khitbah merupakan serangkaian acara yang dilakukan sebelum pernikahan dimulai. Bab I Pasal I KHI menjelaskan bahwa, khitbah nikah adalah kegiatan upaya ke arah terjadinya hubungan perjodohan antara seorang pria dengan seorang wanita. Kamal Muhtar mengartikan khitbah nikah sebagai perryataan atau permintaan dari pihak laki-laki kepada pihak peremuan untuk mengawininya baik dilakukan secara langsung ataupun melalui perantara. Para ulama fikih, mendefinisikan khitbah sebagai keinginana pihak laki-laki kepada pihak perempuan untuk mengawininya dan pihak perempuan menyebarluaskan pertunangan tersebut. Dari uraian tersebut berbeda dengan keadaan di daerah Jatisari Senori Tuban. Yang mana khitbah nikah dilakukan oleh pihak perempuan terlebih dahulu. Bahagaiamana sebenarnya hukum Islam memandang budaya tersebut ? Untuk menjawab permasalahan diatas maka penulis menggunakan metode penelitian yuridis empiris, penelitian hukum sosiologis atau penelitian lapangan dengan mengkaji ketentuan hukum yang berlaku serta yang terjadi di lingkungan masyarakat secara langsung. Adapun hasil penelitian ini adalah; pertama, budaya hukum khitbah nikah yang dilakukan perempuan kepada laki-laki pada masyarakat Jatisari Kecamatan Senosi Kabupaten Tuban, adalah tradisi perilaku, seperangkat nilai, norma yang terbangun oleh budi dan daya masyarakat setempat yang telah terinternalisasi kedalam alam sadaran (mindset) secara turun temurun dan berfungsi sebagai pedoman yang telah dipatuhi oleh masyarakat Jatisari. Dari perilaku masyarakat tersebut, maka terbentuklah budaya hukum yang dipatuhi oleh masyarakat Jatisari. Kedua, praktik khitbah nikah yang dilakukan oleh masyarakat Jatisari ditinjau dari hukum Islam tidak ada permasalahan. Secara spesifik tidak ada larangan khitbah nikah diajukan oleh pihak perempuan.

Kata Kunci: Khitbah, budaya, hukum Islam.
\end{abstract}

\section{Pendahuluan}

Pernikahan merupakan upacara pengikatan janji nikah yang 
dirayakan atau dilaksanakan oleh dua orang dengan maksud meresmikan ikatan perkawinan secara norma agama, norma hukum, dan norma sosial. Upacara pernikahan memiliki banyak ragam dan variasi menurut tradisi suku bangsa, agama, budaya, maupun kelas sosial. Penggunaan adat atau aturan tertentu kadang-kadang berkaitan dengan aturan atau hukum agama tertentu. Pengesahan secara hukum suatu pernikahan biasanya terjadi pada saat dokumen tertulis yang mencatatkan pernikahan. Upacara pernikahan sendiri biasanya merupakan acara yang dilangsungkan untuk melakukan upacara berdasarkan adat istiadat yang berlaku.

Lutfi Hakim dalam bukunya pengantar hukum adat dan hukum Islam mendefinisikan Perkawinan merupakan suatu paguyupan atau somah (jawa: keluarga), dan bukan merupakan suatu hubungan perikatan atas dasar perjanjian. Hubungan suami-istri sebegitu eratnya sebagai suatu ketunggalan. ${ }^{1}$

Kamal Muhtar dalam bukunya asas-asas hukum Islam tentang perkawinan terdapat pengertian bahwa khitbah adalah pernyataan atau permintaan dari seorang laki-laki kepada pihak seorang wanita untuk mengawininya baik dilakukan oleh laki-laki secara langsung atau dengan perantara pihak lain yang dipercayainya sesuai ketentuan agama. ${ }^{2}$ Kompilasi Hukum Islam Bab I Pasal 1 ketentuan umum menyebutkan bahwa khitbah adalah kegiatan upaya ke arah terjadinya hubungan perjodohan antara seorang pria dengan seorang wanita. ${ }^{3}$

Para ulama fikih, medefinisikan khitbah sebagai keinginan pihak lakilaki kepada pihak perempuan untuk mengawininya dan pihak perempuan menyebarluaskan pertunangan tersebut. ${ }^{4}$ Dalam menetapkan hukumnya jumhur ulama mengatakan bahwa khitbah itu mubah. Namum Ibnu Rusyd dalam bidayat al-mujtahid yang mengambil pendapat Daud al-Zhahiriy yang mengatakan hukumnya adalah wajib. Ulama ini mendasarkan pendapanya kepada perbuatan dan tradisi yang dilakukan Nabi dalam khitbah. ${ }^{5}$

\footnotetext{
${ }^{1}$ Lutfi Hakim, Pengantar Hukum Adat dan Hukum Islam, (Yogyakarta: lks, 2004), hlm. 54.

2 Kamal Muhtar, Asas-Asas Hukum Islam Tentang Perkawinan, (Jakarta: Bulan Bintang, 1974), hlm. 28.

3 "Kompilasi Hukum Islam" Bab 1 Pasal 1

${ }^{4}$ Abdul Azis Dahlan, et, al, Ensiklopedi Hukum Islam, Jilid 3, (Jakarta: Ikhtiar Baru Van Hoeve, 1997), Cet. 1. hlm. 927.

${ }^{5}$ Amir Syarifuddin, Hukum Perkawinan Islam di Indonesia, (Jakarta: Kencana,2006), hlm. 50.
} 
Sedangkan budaya khitbah dalam hukum adat adalah sebuah tata cara melakukan pelamaran sebelum berlangsungnya acara perkawinan secara hukum adat. Dalam hukum adat ditentukan bahwa sebelum melangsungkan ikatan perkawinan guna membentuk suatu keluarga atau rumah tangga bahagia, seseorang harus terlebih dahulu melakukan pelamaran dari pihak yang satu kepada pihak yang lain menurut tata cara adat masing-masing masyarakat adat. ${ }^{6}$

Keberadaan budaya sangat mempengaruhi perubahan hukum, seperti budaya hukum di jawa yang menggunakan hukum patrilineal tetapi yang terjadi di Desa Jatisari Kecamatan Senori Kabupaten Tuban orang yang melakukan khitbah itu bukan pihak laki-laki melainkan pihak perempuan yang mekhitbah. Perilaku khitbah yang dilakukan Desa Jatisari yang sama persis dengan budaya hukum di Sumatera, Maka dari itu penulis ingin mengali lebih dalam tentang khitbah yang dilakukan oleh masyarakat Jatisari.

\section{Metode Penelitian}

Jenis penelitian yang digunakan oleh penulis adalah penelitian yuridis empiris. Penelitian yuridis empiris yang dimaksudkan dengan kata lain merupakan jenis penelitian hukum sosiologis dan dapat disebutkan dengan penelitian lapangan, yang mengkaji ketentuan hukum yang berlaku serta yang telah terjadi dalam kehidupan masyarakat. Penelitian ini dengan cara mengkaji praktik Budaya Khitbah Nikah di Desa Jatisari Kecamatan Senori Kabupaten Tuban.

Sejarah Terjadinya Khitbah Nikah yang dilakukan oleh Perempuan Kepada Laki-laki

Menurut beberapa tokoh di Jatisari awal mula terjadinya khitbah nikah yang dilakukan oleh Perempuan kepada laki-laki adalah sebagai berikut;

Pertama K. H. Ahmad Maulani, khitbah nikah perempuan adalah prosesi lamaran yang dilakukan oleh keluarga pihak perempuan terhadap pihak laki-laki dengan disertai musyawarah penetuan hari dan tanggal pernikahan. Ini adalah langkah awal dari hubungan yang mempunyai nilai luhur dan mulia karena melalui khitbah, antara perempuan dan lakilaki bisa saling mengenal satu sama lain, tingkah laku dan agamanya. Di dalam khitbah sudah diatur dalam hukum Islam sedemikian rupa agar

${ }^{6}$ Dewi Wulansari, Hukum Adat Indonesia Suatu Pengantar, (Bandung: Pt Refika Aditama 2010), hlm. 67. 
dalam pernikahan tidak menyesal, meski ketentuan tersebut menyatakan bahwa yang khitbah adalah pihak laki-laki. Namun demikian ada sesuatu hal dan faktor lain yang mendorong mereka untuk tidak sesuai dengan ketentuan yang ada. Itulah yang terjadi di Desa Jatisari bahwa di masyarakat Jatisari mempunyai adat khitbah yang di awali dari pihak perempuan.

Adapun latar belakang sejarah terjadinya khitbah nikah perempuan kepada laki-laki di Desa Jatisari Kecamatan Senori Kabupaten Tuban. Diceritakan pada tahun 1911 kedatangan kyai yang berniat menyebarkan agama Islam di Desa Jatisari, kyai yang alim ilmu agamanya bernama Kyai Malikul Khusna dari Sedan Rembang Jawa Tengah. Ada seorang gadis yang terpikat dengan kealiman ilmu agama yang di miliki Kyai Malikul Khusna yaitu putri Carik konto kepada Kyai Malikul Khusna, Carik Konto adalah kepala desa yang kaya dan terhomat dikalangan masyarakat Jatisari, karena asmara gadis tersebut sudah menggelora, maka diutarakan yang ada dihati gadis tersebut kepada Ayahnda Carik Konto agar segera mengkhitbah Kyai Malikul Khusna. Kemudian Carik Konto bersilaturahmi kerumah Kyai Malikul Khusna, untuk menyampakain keinginannya menikahkan putrinya kepada Kyai Malikul Khusna. Dalam waktu yang tak lama Kyai Malikul Khusna memberikan jawaban kepada Carik Konto menerima perjodohan tersebut, Carik Konto pun mempersiapkan lamaran kepada Kyai Malikul Khusna. Kemudian upacara khitbah pihak perempuan kepada laki-laki dilaksanakan dan masih berjalan sampai sekarang. ${ }^{7}$

Kedua Bapak Yusuf Nawawi, Moden Desa Jatisari, orang jawa itu kalau lihat pemimpinnya melakukan apapun mereka akan mengikuti seperti prosesi peminangan yang dilakukan Carik Konto kepada Kyai Malikul Khusna, masyarakat mengikuti peminangan yang dilakukan Carik Konto dan menjadi teradisi turun temurun yang tak bisa di lepaskan oleh masyarakat Desa Jatisari, apalagi dulu mahar juga dari pihak perempuan, karena begitu inginya orang tua pihak perempuan memiliki seorang menantu yang ahli ibadah dan ahli agama, tetapi pada zaman sekarang tradisi mahar dari pihak perempuan sudah mulai memudar, akan tetapi masyarakat Desa Jatisari masih menggunakan tradisi perempuan yang mengkhitbah laki-laki atau bahasa masyarakat

7 Wawancara dengan K. H. Ahmad Maulani selaku Toko Agama di Desa Jatisari Kecamatan Senori Kabupaten Tuban, Pada hari Kamis 5 Maret 2020 
Desa Jatisari Ngemblok/Ngemblong (Jajanan terbuat dari ketan) dan hanya beberapa masyarakat yang masih mengunakan tradisi keduanya peminangan dan mahar dari pihak perempuan kepada pihak laki-laki, mereka menjalankan tradisi mahar dari pihak perempuan karena meyakini dalam rumah tangga pengantin akan selalu harmonis, pihak keluarga perempuan akan selalu mendapatkan rezeki melimpah dan akan selalu dipermuda urusannya. ${ }^{8}$

Ketiga Ustad Bakir Shodiq, mengatakan tradisi Khitbah yang dilakukan perempuan kepada laki-laki tidak melanggar hukum Islam karena tradisi arab dulu kebanyakan perempuan mengkhitbah laki-laki dengan alasan tertentu, seperti Kisah Siti Khodijah khitbah Nabi Muhammad, karena Siti Khodijah mencari calon suami yang agung. Dapat diketahui bahwa khitbah tidak harus laki-laki yang khitbah dan pihak perempuan yang menunggu, tetapi bisa perempuan yang memulainya jika sudah saatnya untuk berkeluarga, dan tidak usah menunggu terlalu lama. ${ }^{9}$

Jika dilihat dari kondisi masyarakat Desa Jatisari, memang masyarakatnya sangat menghargai dengan tradisi setempat, serta pemikiran penduduknya yang masih alami dan lebih suka mendalami ilmu agama. Begitu juga dalam memilih jodoh lebih suka yang dekat dan apabila anaknya mempunyai hubungan dengan pemuda yang beda desa, dalam khitbahnya juga harus mengikuti tradisi yang berlaku di masyarakat Desa Jatisari.

\section{Praktik Khitbah Nikah oleh Perempuan Kepada Laki-Laki}

Dalam tradisi khitbah seseorang itu akan melewati tiga tahap, yakni naren, ngemblong, dan nembung gunem.

\section{Naren}

Naren adalah percakapan oleh keluarga perempuan kepada keluarga laki-laki, hal ini untuk mengetahui apakah laki-laki yang dipilih belum mempunyai pasangan, Naren ini biasanya dilakukan oleh orang tua (ayah) dari pihak perempuan atau keluarga dekat, naren ini dilakukan dengan cara berkunjung di rumah keluarga lakilaki. Peran orang tua pada saat naren adalah menjelaskan maksud kedatangan keluarga perempuan, yaitu menanyakan secara langsung

\footnotetext{
8 Wawancara dengan Bapak Yusuf Nawawi selaku Moden di Desa Jatisari Kecamatan Senori Kabupaten Tuban, Pada hari Kamis 5 Maret 2020

${ }_{9}$ Wawancara dengan Ustad Bakir Shodiq selaku Toko Agama di Desa Jatisari Kecamatan Senori Kabupaten Tuban, Pada hari jum'at 6 Maret 2020
} 
apakah anak laki-laki yang akan di-ngemblok benar-benar belum mempunyai pasangan. Pada saat naren biasanya dengan membawa gula dan kopi sepantasnya sebagai hadiah kepada keluarga pria.

2. Ngemblong

Ngemblong sama artinya dengan khitbah. Pada dasarnya, tradisi ngemblong pada masyarakat Jatisari identik dengan khitbah nikah. Tradisi ngemblong pada umumnya dilaksanakan setelah proses naren (bertanya), dalam jangka waktu yang sudah di tentukan kedua pihak keluarga. Ngemblong ini merupakan khitbah nikah secara resmi yang dilakukan pihak perempuan kepada pihak laki-laki. Pihak-pihak yang ikut dalam prosesi ngemblong dari keluarga perempuan yaitu ayah, ibu, beberapa keluarga dekat dan sesepuh dalam keluarga pihak perempuan, Sajian yang di bawa keluarga pihak perempuan beras ketan (gemblong) dan wajik (ketan salak).

3. Nembung Gunem

Nembung gunem adalah Mengingat Kesepakatan, dalam acara ini sebenarnya hanya menginformasikan dari keluarga pihak laki-laki kepada keluarga pihak perempuan, mengambil keputusan tentang hal-hal teknis acara pernikahan nanti.

Analisisa Budaya Khitbah Nikah oleh Perempuan Kepada Laki-laki di Desa Jatisari Senori Tuban

Khitbah nikah adalah pendahuluan sebelum dilaksanakan ikatan pernikahan agar masing-masing pasangan yang akan menikah mengenal pasangannya, sehingga mendapatkan kemantapan hati untuk melaksanakan pernikahan. Pada umumnya di Jawa khitbah nikah dilakukan oleh seorang laki-laki kepada seorang perempuan, namun ada juga dari pihak perempuan mengkhitbah seorang laki-laki seperti di Minangkabau yang menganut sistem kekeluargaan matrilineal yang mengatur alur keturunan dari ibu. Berbeda dengan sistem kekeluagaan patrilineal yang mengatur alur keturunan berasal dari pihak ayah seperti di Jawa, Batak, Gayo dan Lampung.10

Dari abad ke abad sejarah hukum mencatat sistem hukum menjadi kompleks dan rumit, hal tersebut seiring dengan kehidupan masyarakat yang terus berkembang secara dinamis dari waktu ke waktu, sehingga

10 Soerojo Wignjodipoero, Pengantar dan Asas-Asas Hukum Adat, (Jakarta: PT Toko Gunung Agung, 1995), hlm. 109. 
muncul tuntutan untuk melakukan berbagai perubahan. ${ }^{11}$ Hukum sebagai sarana pembaruan masyarakat ditandai dengan adanya perkembangan dan perubahan tersebut. ${ }^{12}$

Kebudayaan dan sistem hukum pada dasarnya mencakup nilai-nilai yang mendasari hukum yang berlaku, nilai-nilai yang merupakan konsepsi abstrak mengenai apa yang di anggap baik (sehingga dianut) dan apa yang di anggap buruk (sehingga dihindari). Pasangan nilai yang berperan dalam hukum, adalah sebagai berikut: ${ }^{13}$

a. Nilai ketertiban dan nilai ketentraman.

b. Nilai jasmani dan nilai rohani.

c. Nilai kelanggengan/konservatisme dan nilai kebaruan.

Dalam tiap-tiap masyarakat dikembangkan serentetan pola-pola budaya ideal dan pola-pola budaya itu cenderung diperkuat dengan adanya pembatasan-pembatasan kebudayaan. Pola-pola budaya yang ideal itu memuat seperti hal-hal yang oleh sebagian besar dari suatu masyarakat diakui sebagai kewajiban yang harus dilakukannya dalam keadaan-keadaan tertentu. Pola-pola ideal seperti itu sering disebut norma-norma. ${ }^{14}$

Pelaksanaan khitbah nikah perempuan yang menjadi tradisi masyarakat Jatisari Kecamatan Senori Kabupaten menjadi tradisi masyarakat Jatisari Kecamatan Senori Kabupaten Tuban. Adapun faktor penyebab terjadinya khitbah nikah perempuan ini mempunyai tujuan dengan maksud agar anak perempuannya mendapatkan jodoh yang baik tingkah lakunya dan budi pengertinya, masyarakat Jatisari masih memangang erat budaya yang telah lahir dari nenek moyang, untuk meninggalkannya masyarakat Jatisari sangat menakutinya. Adapun praktek khitbah nikah yang dilakukan oleh pihak perempuan kepada lakilaki, yaitu yang dikenal oleh masyarakat dengan sebutan ngemblong (jajanan dari ketan), filosofinya adalah pengantin sebagai suami isteri agar bisa tetap melihat ketan yang tak bisa dipisahkan satu sama lain ${ }^{15}$.

Kebiasaan yang dilakukan di desa Jatisari dengan sebutan ngemblong

\footnotetext{
${ }^{11}$ Amran Saudi dan Mardi Candra. Politik Hukum Perspektif Hukum Perdata, hlm. 4.

12 Amran Saudi dan Mardi Candra. Politik Hukum Perspektif Hukum Perdata dan Pidana Islam Serta Ekonomi Syari'ah, hlm. 7.

${ }^{13}$ Amran Suadi, Sosiologi Hukum: Penegakan, Realitas dan Nilai Moralitas Hukum, hlm. 270

${ }^{14}$ T.O Ihromi, Pokok-Pokok Antropologi Budaya, hlm. 27.

15 Wawancara dengan Bapak Yusuf Nawawi selaku Moden di Desa Jatisari Kecamatan Senori Kabupaten Tuban, Pada hari Kamis 5 maret 2020
} 
sudah menjadi tradisi turun temurun oleh masyarakat Jatisari. Masyarakat sangat patuh dengan tradisi ngemblong, masyarakat berkeyakinan menjalankan tradisi ini akan mendapatkan keberkahan dan keharmonisan dalam rumah tangga anaknya.

Namun khitbah nikah perempuan kepada laki-laki merupakan kontroversi yang banyak menimbulkan pro dan kontra karena dalam sistem kekerabatan yang ada di jawa menganut sistem patrilineal dalam ketentuannya khitbah diawali oleh pihak laki-laki, tetapi di masyarakat Jatisari melakukan khitbah yang di awali oleh pihak perempuan seperti yang dilakukan oleh suku Minangkabau yang mengikuti sistem kekerabatan matrilineal.

Perlambangan perilaku dalam acara pernikahan di Desa Jatisari Kecamatan Senori Kabupaten Tuban yang menunjukan perbedaan hukum adat lokal. Dengan demikian perlambangan dan tanda-tanda perilaku yang dilakukan masyarakat Jatisari mempunyai arti dan membawa akibat hukum dalam susunan masyarakat bersangkutan. Dari tanda-tanda itu dapat diperkirakan bagaimana sistem hukum dan konsepsi hukum masyarakat tertentu. ${ }^{16}$

Perilaku hukum satu masyarakat berbeda dengan perilaku hukum di masyarakat yang lain. Sehingga karena demikian maka budaya hukum tertentu belum tentu diterima oleh budaya yang lain. Dengan demikian budaya hukum bersifat penerimaan atau penolakan terhadap suatu peristiwa hukum. Dalam pendekatan budaya hukum dan antropologi sangat erat kaitannya dengan sebuah kebudayaan. Di mana setiap masyarakat dalam suatu kelompok yang memiliki sifat individu yang berbeda-beda akan memiliki reaksi yang sama terhadap gejala-gejala tertentu dalam suatu masyarakat, reaksi ini yang di sebut sebagai kebudayaan. ${ }^{17}$

Masyarakat Jatisari masih tergolong dalam tipe budaya hukum masyarakat parokial (picik) yang cara berfikir para anggota masyarakatnya masih terbatas, maka tanggapannya terhadap hukum hanya terbatas dalam lingkungannya sendiri. Masyarakat demikian masih kuat bertahan pada tradisi hukumnya sendiri, kaidah-kaidah hukum yang telah digariskan dari zaman leluhur merupakan azimat yang pantang diubah, barang siapa berperilaku menyimpang dari norma-norma leluhur

${ }^{16}$ Hilman Hadikusuma, Antropologi Hukum Indonesia, hlm. 64.

17 T.O Ihromi, Pokok-Pokok Antropologi Budaya, hlm. 13. 
itu akan mendapatkan kutukan yang gaib. ${ }^{18}$

Perilaku budaya hukum yang dilakukan oleh masyarakat Jatisari. Budaya hukum adalah seperangkat nilai, norma yang terbangun oleh budhi dan daya masyarakat setempat dan telah terinternalisasi kedalam alam kesadaran (mindset) secara turun temurun dan berfungsi sebagai pedoman yang menghubungkan antara peraturan-peraturan hukum pada tataran teori di satu pihak dan perilaku, tindakan nyata pada tataran praksis di lain pihak yang diharapkan masyarakat. Friedman memperkenalkan konsep budaya hukum yang diartikan sebagai alat untuk mempertegas fakta bahwa hukum paling baik dipahami dan digambarkan sebagai sebuah sistem hukum.

Friedman memperkenalkan bahwa ada tiga unsur yang mempengaruhi bekerjanya hukum, yaitu:

a. Struktur Hukum (Legal Structure) adalah seperangkat kelembagaan yang diciptakan untuk mendorong bekerjanya sistem hukum itu sendiri.

b. Substansi Hukum (Legal Substance) adalah aturan atau norma yang merupakan pola perilaku masyarakat dan produk (output) dari bekerjanya struktur hukum.

c. Budaya Hukum (Legal Culture) adalah seperangkat nilai-nilai yang terdiri dari kekuatan sosial dan hukum yang dijadikan sebagai pengikat bekerjanya struktur hukum.

Dapat diartikan dari definisi di atas, Hukum adalah sebuah hasil dari proses menyatuhnya antara unsur kekuatan-kekuatan sosial (social forces) dan kekuatan-kekuatan (legal forces) sebagai input, yang kemudian menghasilkan hukum. Dengan sendirinya produk hukum yang disebut terakhir merupakan saluran dari kekuatan-kekuatan sosial dan kekuatankekuatan hukum yang memiliki dampak ketertiban hukum masyarakat sebagai outcome. ${ }^{19}$

Dengan begitu budaya hukum yang mengatur masyarakat harus dianut dan dipertahankan, tidak hanya berhubungan dengan pergaulan antar sesama manusia dan alam nyata, tetapi mencakup kepentingan yang bersifat batiniah dan struktur rohaniah berhubungan dengan kepercayaan yang mereka anut dan hormati. Seseorang menggunakan atau tidak menggunakan hukum, dan patuh atau tidak patuh terhadap hukum

\footnotetext{
18 Hilman Hadikusuma, Antropologi Hukum Indonesia, (Bandung: Alumni, 1986),hlm. 54

${ }^{19}$ Lawrence M. Friedman, Sistem Hukum: Prespektif Ilmu Sosial, (Bandung: Nusa Media, 2017), hlm. 15-16
} 
sangat tergantung komponen-komponen yang ada dalam budaya hukumnya. Meskipun disebutkan bahwa dalam hukum terdiri dari tiga komponen, yaitu struktur, substansi, dan budaya hukum. Karena sebaik apapun hukum dibuat, tetapi pada akhirnya keberhasilan hukum akan ditentukan oleh budaya hukum masyarakat yang bersangkutan.

Khitbah nikah perempuan adalah tradisi yang telah ada sejak nenek moyang masyarakat Jatisari, yang harus dilakukan semua masyarakat Jatisari untuk menghormati peninggalan nenek moyang. Meskipun dalam sistem kekerabatan Jawa menganut sistem patrilineal tetapi masyarakat Jatisari mengikuti sistem matrilineal. Dalam praktik khitbah nikah perempuan kepada laki-laki kalau tidak dilakukan semuanya dan secara urut akan menimbulkan sanksi sosial yang belaku pada masyarakat Jatisari, seperti merasa malu terhadap masyarakat sekitar. Walaupun begitu masyarakat Jatisari tidak melanggar hukum adat karena tradisi yang dilakukan masyarakat Jatisari termasuk berperilaku budaya hukum. Karena dalam kelahiran budaya hukum berasal dari proses internal selama perkembangan masyarakat berlangsung, dan selama itu pula interaksi baik antar warga maupun antara warga dengan warga dari luar berlangsung membentuk perilaku yang semakin mempola dan akhirnya pola tindakan dianggap sebagai yang benar dan dijadikan pedoman bertindak oleh sebagian besar masyarakat. ${ }^{20}$

Jadi khitbah nikah perempuan/ngemblong boleh dilakukan oleh masyarakat Jatisari, karena masyarakat Jatisari tidak melanggar hukum adat dan budaya hukum dalam bermasyarakat. masyarakat Jatisari berpedoman bahwasanya ngemblong adalah tradisi yang harus dilestarikan dan dilakukan semua Masyarakat Jatisari. Masyarakat merasa ngemblong bukan hal aneh, di mana pihak keluarga perempuan meminta untuk khitbah keluarga laki-laki. Tetapi banyak yang mengatakan bahwa hal ini tersebut tidak lazim untuk dilakukan. Tetapi kalau sudah urusan dengan tradisi masyarakat tidak bisa meninggalkan tradisi ini, karena keyakinan yang telah tertanam di alam bawah sadar masyarakat Jatisari. Yang paling penting tradisi ngemblong bukan melanggar hukum adat dan budaya hukum.

Di dalam hukum Islam khitbah nikah merupakan sub sistem dari keseluruhan yang mengatur pernikahan. Khitbah merupakan sebuah aksi (fi'lah), ikatan ('iqdah), dan posisi (jilsah). Pelaku khitbah disebut khatib

${ }^{20}$ Ade Saptomo, Budaya Hukum dan Kearifan Lokal, hlm. 42. 
dan khitb, yaitu orang yang mengkhitbah perempuan, terdapat di dalam firman Allah SWT dalam surat Al-Baqarah (2) ayat 235: yang artinya;

Dan tidak ada dosa bagimu meminang perempuan-perempuan itu dengan sendirian". (Q.S. al-Baqarah: 235).

Para ulama fiqh, medefinisikan khitbah sebagai keinginan pihak lakilaki kepada pihak perempuan untuk mengawininya dan pihak perempuan menyebarluaskan pertunangan tersebut. ${ }^{21}$ KHI juga menjelaskan pada Bab I, Pasal 1, bahwa khitbah (peminangan) adalah kegiatan upaya ke arah terjadinya hubungan perjodohan antara seorang pria dengan seorang perempuan. ${ }^{22}$ Khitbah merupakan langkah awal yang dilakukan oleh laki-laki kepada perempuan untuk di jadikan istri. Dalam menjalankan khitbah diharapkan dari pihak laki-laki dan pihak perempuan untuk saling mengenal, mengetahu kelebihan dan kekurangan. Agar kelak membangun rumah tangga tidak ada rasa kekecewan kedua pihak dan bisa saling menutupi kekurangan pasangannya.

Adapun syarat-syarat khitbah di jelaskan dalam kompilasi hukum Islam (KHI) yang berbunyi Pada pasal 12 dalam Kompilasi Hukum Islam (KHI) menerangkan tentang syarat-syarat khitbah nikah, yang berbunyi:

1) Peminangan dapat dilakukan terhadap seorang wanita yang masih perawan atau terhadap janda yang telah habis masa iddahnya.

2) Wanita yang ditalak suami yang masih berada dalam masa iddah raj'iah, haram dan dilarang untuk dikhitbah.

3) Dilarang juga meminang seorang wanita yang sedang dipinang pria lain, selama pinangan pria tersebut belum putus atau belum ada penoklakan dari pihak wanita.

4) Putusnya pinangan pihak pria, karena adanya pernyataan tentang putusnya hubungan pinangan atau secara diam-diam pria yang meminang telah menjauh dan meninggalkan wanita yang dipinang. ${ }^{23}$

Dari penjelasan di atas nampak jelas bahwa peminangan atau khitbah selalu datang dari pihak laki-laki kepada pihak perempuan, baik dilakukan secara langsung oleh si peminang maupun diwakilkan kepada walinya. Adapun pendapat Imam Bukhari tentang khitbah yang dilakukan oleh pihak perempuan yaitu bahwa ketika ia mengetahui adanya kekhususan pada kisah perempuan yang menyerahkan dirinya

${ }^{21}$ Abdul Azis Dahlan, et al., Ensiklopedi Hukum Islam, hlm. 927

${ }^{22}$ Kompilasi Hukum Islam "Bab 1 Pasal 1"

${ }^{23}$ Kompilasi Hukum Islam "Bab 1 Pasal 12" 
maka beliau menyimpulkan dari Hadits pernyataan yang tidak menunjukkan kekhususan, yaitu pembolehan bagi perempuan menawarkan dirinya kepada laki-laki yang shalih karena menginginkan keshalihannya, maka hal itu diperkenankan. Jika laki-laki shalih tersebut menyukainya, maka dia dapat menikahi perempuan tadi sesuai syaratsyarat nikah. ${ }^{24}$

Namun berbeda yang dilakukan oleh masyarakat Desa Jatisari Kecamatan Senori Kabupaten Tuban. Di desa tersebut masyarakatnya menggunakan khitbah nikah perempuan. Dalam hal ini perempuanlah yang melakukan khitbah kepada laki-laki. Adapun alasan masyarakat masih melaksanaan khitbah nikah perempuan yaitu masyarakat masih mematuhi tradisi leluhur dan masyarakat menyakini kelak setelah menikah kedua pihak dalam rumah tangganya akan diberikan keberkahan. Masyrakat Jatisari merasa tradisi khitbah perempuan harus selalu dilestarikan. Khitbah nikah perempuan terkenal dikalangan masyarakat dengan sebutan Ngemblong.

Memang terdapat dalam al-Qur'an dan hadis Nabi yang membicarakan hal khitbah. Namun tidak ditemukan secara jelas dan terarah adanya perintah atau larangan melakukan khitbah. Sebagimana perintah untuk mengadakan perkawinan dengan kalimat yang jelas, baik dalam Al-Qur'an maupun dalam hadis Nabi SAW. ${ }^{25}$ Di mana produk hukum yang dilakukan sesuai dengan keadaan di mana masyarakat itu berada, sehingga hukum yang dilakukan di masyarakat Arab belum tentu aktual dengan masyarakat yang berbudaya lain. Hal ini di sebabkan karena perubahan masa, tempat menghendaki kemaslahatan yang sesuai dengan keadaan masa itu, dan ini mempunyai pengaruh besar terhadap pertumbuhan hukum, karena hukum itu tumbuh dan berkembang dalam masyarakat.

Islam memandang tradisi sebagai suatu hal yang dapat ditoliler sejauh tidak bertentangan dengan undang-undang dan agama, serta tidak berkaitan dengan kepercayaan yang menjerumuskan kepada kemusyrikan. Dalam khitbah nikah perempuan harus mempunyai tujuan yang baik dan tidak bertentangan agama. Hal ini yang dijelaskan dalam kaidah-kaidah hukum Islam, yaitu:

${ }_{24}$ Al Imam Al Hafizh Ibnu Hajar Al-Asqalani, Fathul Baari Syarah Shahih Al Bukhari, Penjelasan Kitab Shahih Al Bukhari, hlm. 250-251.

${ }^{25}$ Amir Syarifuddin, Hukum Perkawinan Islam Di Indonesia, hlm. 50. 
"Segala perkara tergantung pada tujuannya." 26

Dalam hal sabda Nabi SAW. Yang diriwayatkan oleh perawi enam dari Umar Ibn Al Khathtab, yaitu:

"Segala amal berbuatan hanya dengan niat dan bagi seseorang hanyalah apa yang ia niatkan." 27

Dari keterangan tersebut, bisa diketahui bahwa sesuatu perkara yang tujuannya baik, akan mendapatkan kebaikan apa yang ia diniatkan. Seperti khitbah nikah perempuan kepada laki-laki yang dilakukan oleh masyarakat Desa Jatisari Kecamatan Senori Kabupaten Tuban. Masyarakat mempunyai niat dan tujuan yang baik dalam praktik khitbah nikah perempuan. Tujuan masyarakat Jatisari adalah mendapatkan menantu yang sholeh dan baik budi pengertinya.

Dalam realitas khitbah nikah perempuan yang ada pada masyarakat Jatisari Kecamatan Senori Kabupaten Tuban, berjalan terus menerus sesuai dengan kemaslahatan manusia karena berubahnya gejala sosial kemasyarakat. Oleh karena itu, kemaslahatan manusia itu menjadi dasar setiap macam hukum. Maka sudah menjadi kewajaran apabila terjadi perubahan hukum. Dalam penghapusan kemadharatan akan mendatangkan kemaslahatan bagi kehidupan manusia, mereka memandang bahwa adat yang mereka lakukan telah memberikan kehidupan baru sehingga diprakarsai oleh perempuan dianggap tradisi yang baik bagi masyarakat Islam Jatisari. Hal ini yang dijelaskan dalam kaidah-kaidah hukum Islam, yaitu:

"Kebutuhan itu dapat menepati tempatnya darurat, baik kebutuhan umum maupun kebutuhan khusus." 28

Kaidah di atas menjelaskan bahwa keringanan itu tidak hanya berlaku pada kemadharatan, tetapi juga berlaku pada kebutuhan (hajat), baik kebutuhan umum maupun kebutuhan khusus.

Dapat ditarik kesimpulan bahwa khitbah nikah perempuan yang dilakukan oleh masyarakat Desa Jatisari Kecamatan Senori Kabupaten Tuban hukumnya boleh dan tidak melanggar hukum Islam. Karena tradisi ngemblong yang telah ada sejak nenek moyang ini tidak ada unsur kemusyrikan dan menghalalkan yang haram atau sebaliknya. Dan dapat diketahui bahwa khitbah tidak harus laki-laki yang khitbah dan pihak

${ }^{26}$ A. Ghozali Ihsan, Kaidah-Kaidah Hukum Islam, (Semarang: Basscom Multimedia Grafika, 2015) Cet 1. Hlm. 18.

27 A. Ghozali Ihsan, Kaidah-Kaidah Hukum Islam, hlm. 19

${ }^{28}$ A. Ghozali Ihsan, Kaidah-Kaidah Hukum Islam, hlm. 20 
perempuan yang menunggu, tetapi bisa perempuan yang memulainya jika sudah saatnya untuk berkeluarga, dan tidak usah menunggu terlalu lama.

Adapun pendapat Imam Bukhari tentang khitbah yang dilakukan oleh pihak perempuan yaitu bahwa ketika ia mengetahui adanya kekhususan pada kisah perempuan yang menyerahkan dirinya maka beliau menyimpulkan dari Hadits pernyataan yang tidak menunjukkan kekhususan, yaitu pembolehan bagi perempuan menawarkan dirinya kepada laki-laki yang shalih karena menginginkan keshalihannya, maka hal itu diperkenankan. Jika laki-laki shalih tersebut menyukainya, maka dia dapat menikahi perempuan tadi sesuai syarat-syarat nikah. ${ }^{29}$

\section{Penutup}

Budaya hukum khitbah nikah yang dilakukan perempuan kepada laki-laki pada masyarakat Jatisari Kecamatan Senori Kabupaten Tuban, adalah suatu tradisi, perilaku seperangkat nilai, norma yang terbangun oleh budi dan daya masyarakat setempat dan telah terinternalisasi kedalam alam kesadaran (mindset) secara turun temurun dan berfungsi sebagai pedoman yang telah di patuhi oleh masyarakat Jatisari. Maka dari perilaku masyarakat yang terus menurus terbentuk budaya hukum yang sebaiknya dipatuhi oleh masyarakat Jatisari Kecamatan Senori Kabupaten Tuban.

Khitbah perempuan kepada laki-laki yang selama ini dilakukan oleh masyarakat Jatisari Kecamatan Senori Kabupaten Tuban, jika ditinjau dari hukum Islam khitbah nikah perempuan tidak ada permasalahan. Karena secara spesifik, tidak ada larangan bagi seorang perempuan apabila ingin mengajukan diri kepada seorang laki-laki yang dianggap sholeh dan baik untuk diajak menikah. Hal seperti itu sudah ada sejak zaman Nabi Muhammad SAW, yaitu pada kisah Sayyidah Khodijah mengkhitbah Nabi Muhammad SAW, Karena Sayyidah Khodijah mengetahui persis kebaikan akhlak beliau.

\section{Daftar Pustaka}

\section{KUHPerdata}

Kompilasi Hukum Islam

Abdul Azis Dahlan. et, al, Ensiklopedi Hukum Islam. Jilid 3, Jakarta: Ikhtiar Baru Van Hoeve, 1997.

${ }^{29}$ Al Imam Al Hafizh Ibnu Hajar Al-Asqalani, Fathul Baari Syarah Shahih Al Bukhari, hlm. 250-251. 
Al Imam Al Hafizh Ibnu Hajar Al-Asqalani. Fathul Baari Syarah Shahih Al Bukhari, Penjelasan Kitab Shahih Al Bukhari jilid 9. Terj. Syaikh Abdul Aziz Abdullah bin Baz. Jakarta: Pustaka Azzam, 2015.

Amir Syarifuddin. Hukum Perkawinan Islam di Indonesia. Jakarta: Kencana, 2006.

Amran Saudi dan Mardi Candra. Politik Hukum Perspektif Hukum Perdata dan Pidana Islam serta Ekonomi Syari'ah. Jakarta: Prenadamedia, 2016.

Amran Suadi. Sosiologi Hukum: Penegakan, Realitas dan Nilai Moralitas Hukum. Jakarta: Prenadamedia, 2019.

Dewi Wulansari. Hukum Adat Indonesia Suatu Pengantar. Bandung: Pt Refika Aditama, 2010.

Ghozali Ihsan. Kaidah-Kaidah Hukum Islam. Semarang: Basscom Multimedia Grafika, 2015.

Hilman Hadikusuma. Antropologi Hukum Indonesia. Bandung: Alumni, 1986.

Kamal Muhtar. Asas-Asas Hukum Islam Tentang Perkawinan. Jakarta: Bulan Bintang, 1974.

Lawrence M. Friedman. Sistem Hukum: Prespektif Ilmu Sosial. Terj. M. Khozim. Bandung: Nusa Media, 2017.

Lutfi Hakim. Pengantar Hukum Adat dan Hukum Islam. Yogyakarta: lks, 2004.

Soerojo Wignjodipoero. Pengantar dan Asas-Asas Hukum Adat. Jakarta: PT Toko Gunung Agung, 1995.

Wawancara dengan K. H. Ahmad Maulani selaku Toko Agama di Desa Jatisari Kecamatan Senori Kabupaten Tuban, Pada hari Kamis 5 Maret 2020.

Wawancara dengan Bapak Yusuf Nawawi selaku Moden di Desa Jatisari Kecamatan Senori Kabupaten Tuban, Pada hari Kamis 5 Maret 2020.

Wawancara dengan Ustad Bakir Shodiq selaku tokoh Agama di Desa. 